'Today, how can we not speak of the university?' Towards the next generation...

(To appear in Power and Education, 2012.

Please cite as:

Watson, C. (forthcoming) 'Today, how can we not speak of the university?' Towards the next generation... Power and Education.

\title{
Cate Watson
}

University of Stirling

cate.watson@stir.ac.uk 
'Today, how can we not speak of the university?' Towards the next generation...

\begin{abstract}
Universities are currently in a period of transition as the Humboldtian institution reaches its limits and we move towards the next generation. These limiting factors include the massive expansion of higher education and increase in student numbers; globalisation; and demands that universities contribute to the development of the 'knowledge economy'. Change is inevitable - but does this leave the university in crisis? Is the university still a functional institution? In this paper my aim is to uncover just how far we have gone in this transition towards the next generation institution; to celebrate those institutions that have embraced these opportunities; and to consider the implications of all this guided by (and providing a partial answer to) the question once posed by Jacques Derrida: 'Today, how can we not speak of the university?' The paper concludes by considering whether there is room for a dysfunctional university, a university that in a sense opposes the call for functionality? In other words, is there (still) a role for a university as a critical and radical institution?[1]
\end{abstract}

\title{
Introduction
}

'The university is dead', Ronald Barnett provocatively declared in 1997 (p.1); though three years later the university had clearly rallied and Barnett suggested the less catchy, although altogether more academically cautious, the university is (perhaps) attenuated (2000, p.14) before concluding triumphantly that au contraire we are witnessing the arrival of the 'expanding university' (2000, p. 16). While there may be pessimists among us who might 
prefer to dwell, nostalgically, in the ruins of the pre-expanded university others are more sanguine. One of these latter is J.G. Wissema (2009) who argues that we are currently in a period of transition as the 'second generation university', characterised as the Humboldtian institution, reaches its limits and we move towards the third generation university, the $3 \mathrm{GU}$. The 3GU is, Wissema says, 'both inevitable and desirable' (p. xvi). Inevitable because of the 'trends that are destroying the 2GU' and desirable because of the rewards on offer to those institutions that can make the transition. These trends include the massive expansion of higher education and increase in student numbers; globalisation; and demands that universities contribute to the development of, what EU Commissioner, Jan Figel, has referred to intriguingly as 'a true knowledge economy' (Europa Communiques de Presse Rapide, 2006, emphasis added). But Wissema is optimistic about the future of the university (p. xvi): 'The 3GU is not' he maintains 'a commercial enterprise in which everything is geared to profit maximisation...Rather, it continues to be true to its mission: to create new knowledge and to make education part of the knowledge-creating process'. So why bother worrying about the future of the university? Let's just climb on the 'knowledge carousel' (p. xvi), that giddy whirl linking universities, industry, financiers, et al and enjoy the ride...

In this paper my aim is to uncover just how far we have gone in this transition towards the 3GU; to celebrate those institutions that have embraced these opportunities; and to consider the implications of all this guided by (and providing a partial answer to) the question posed by Jacques Derrida (1983), 'Today, how can we not speak of the university?' 
Derrida suggests there are two ways to (not?) think about this question. Firstly, he says, it is 'impossible...to dissociate the work we do...from a reflection on the political and institutional conditions of that work' $(1983$, p.3). Though some would argue that this is precisely what many academics have been able to do: May (2005, p. 200) observes that in the coveted pursuit of 'world class' status there has been 'a relative silence from those "critical" academics who enjoy its privileges, thereby signalling evident limits to reflexive thought'. But, secondly, there is a preventative notion in the negative 'how can we not speak' - which suggests, how should we not speak of the university, what are the risks involved and the dangers to be avoided; the 'bottomless pits' and 'protectionist barriers' in thinking about the university and the 'principle of reason' which underpins it. For, Derrida goes on, 'as far as I know, nobody has ever founded a university against reason' (p.7). This paper, therefore is offered as a reflexive consideration of the work we do, and asks are there ways in which we cannot (should not) speak of 'the university' (if we still expect it to adhere to the principle of reason). To start with, however, I want to set out what is meant by the $3 \mathrm{GU}$.

\section{Towards the 3GU}

Wissema sets out a trajectory from the medieval 1GU, which had as its objective education and defined its role as 'defending the truth'[2]; through the Humanist 2GU, engaged in research as well as education and with the purpose of 'discovering nature'; to the university of the future, the 3GU, which adds 'know-how exploitation' to its brief and has the objective of 'creating value' (p.23). In moving to the 3GU Wissema sets out seven challenges:

\section{1. development of entrepreneurial activity for the exploitation of know-how}


2. ability to operate in an internationally competitive market for the best academics, students and research grants

3. developing networks and collaborations with industry and other universities

4. developing interdisciplinarity and embracing consilience 'as a driving force of similar importance to the rational scientific method'

5. becoming a multicultural organisation...

6. developing a cosmopolitan outlook

and finally,

7. becoming 'less dependent on state regulation'

Knowledge exploitation becomes the core business of the 3GU uniting both the teaching and the research functions of the university, and harnessing both for the 'creation of value' (as discursively defined). Thus, new knowledge is created through research and must be shown to have 'impact' (even in advance of its creation); and knowledge can be packaged and sold to potential clients within an international marketplace. From this logic all else flows (and consequences, for institutions and those who work and study within them, obtain). Thus, the development of networks and collaboration between industry and other universities becomes necessary as the cost of 'cutting edge' research rises and state funding is reduced; the development of 'mode 2' contextual and applied knowledge (Gibbons et al, 1994) requires the breaking down of the disciplines, and the rise of the 'university institute' which cuts across traditional departmental boundaries; internationalisation demands the development of multicultural universities which, interestingly, Wissema interprets not only as operating within an international market, but as the establishment of a 'two-track' mass/elite system, 
offering 'standard' courses for the majority of students and 'science-oriented academic courses to the best and brightest' (p. 40) (there are shades of C.P. Snow in this definition); cosmopolitanism, Wissema defines rather ironically as having English as the 'daily language' and 'learning to work with diversity' (p. 41), a feature he claims lost in the nationalistic tendencies of the $2 \mathrm{GU}$.

Wissema's final challenge - less dependence on state regulation - seems rather a vain aspiration in the current context which has seen a trend towards more state interference along with less state funding. We are not seeing 'the retreat of the state' (Delanty, 2001, p.151) except insofar as direct state funding of teaching and research are concerned, indeed, here in the UK successive governments' attempts to manipulate the market in which universities operate are all too evident. This is certainly the case in England at present where David Willetts, the minister responsible for Higher Education in the current Conservative-Liberal Democrat coalition government, has set out to redefine the parameters of the market reinforcing the moves which have seen, over a series of administrations, higher education become a private rather than a public good: 'human capital being individualized according to its capacity to be activated in a future job market as a result of possessing the right credentials’' (May, 2005, p. 197).

What we might call the functional model of the university (or utilitarian [Robins and Webster, 2002] or pragmatic [Doherty, 2011]) is not, of course, new and has existed alongside the liberal model in which knowledge is viewed 'as an end in itself' in a productive (if ambiguous) tension which has been perhaps the hallmark of the $2 \mathrm{GU}$. This alliance, 
Robins and Webster argue (2002, p. 9) 'made sense in terms of an agenda determined by the economic and cultural objectives of nation-states within a national project and agenda for higher education' (ibid). It is this link that is, according to Readings (1996, p. 39), severed once the university goes global and the principle of reason becomes the 'appeal to excellence', an idea with no content, leaving the university a 'ruined' national institution.

In order to explore these indicators of functionality, symptomatic of the principle of reason in the 3GU, I take an empirical approach, conducting an ironic analysis (Watson, 2011) of sources of largely ephemeral data, notably the Times Higher Education supplement (THE) [3], which examines the moves universities have made in embracing the challenge of the 3GU, and drawing out the lessons for those who desire and aspire to World Class status. A status which has become, in terms of the Lacanian discourse of the university, the Master signifier: one with which many within the institution will identify imagining that in belonging to such an institution, they too will acquire World Class status (Bailey, 2009, p.159) while others 'feel more and more helpless, small and castrated by the institution over the years...' (ibid). All this, as has been widely recognised and experienced by academics, has required a shift in the governance and management of universities and the language of performativity; new public management; neoliberalism; managerialism etc is in every academic's vocabulary (and too well-worked over to go into here - see for example Olssen and Peters, 2005). The transition to the $3 \mathrm{GU}$ has significant implications for those working within the academy, and an examination of these forms a key part of the exploration of functionality offered in this paper. 
Examining the Indicators of Functionality in the 3GU

These seven challenges for the $3 \mathrm{GU}$ can be operationalised giving rise to a series of performance indicators which can be used to determine functionality and fitness for purpose of the university whose principle of reason is 'the creation of value' in the pursuit of excellence through the exploitation of knowledge in a global market. In this next section therefore I present a handy checklist with exemplars in order that the functional university can assess just where it is on the trajectory to World Class status.

\section{Characteristics of the 3GU:}

1. Exploitation of knowledge is core business; entrepreneurialism.

2. Operates in an international competitive market.

3. Open, collaborating with many partners.

4. Emphasis on transdisciplinary research; rise of institutes.

5. Multicultural; provides mass and elite education.

6. Cosmopolitan.

7. No direct state funding. No state interference.

(after Wissema, 2009, p. 32)

Exploitation of knowledge requires the adoption of an entrepreneurial outlook with the aim of becoming less dependent on state funding for core activities. This encompasses activities such as: the formation of 'carve outs' for the packaging and sale of professional knowledge; 
exploitation of the knowledge created through research - 'spin outs' (or offs), 'technostarters' and the like; and raising cash from benefactors through the exploitation of symbolic capital.

A carve out is a subsidiary company which is not wholly spun off from the parent organisation, for example, Duke Corporate Education, a carve out from Duke University's Business School, recently 'ranked the world's number one provider of custom executive education' by the Financial Times' for the 9th consecutive year[4]. With a reported revenue of \$38 million in 2010 [5] this is a model other universities may be tempted to emulate. More common than carve outs are spin offs and despite the Daily Telegraph [6] reporting a collapse in spin-off activity following the 2008 Crash this is still clearly an area of considerable activity with Edinburgh University leading the way in the UK (Scotsman, 21.04.2011[7]). However, a report (Targeting innovation, 2008), which tracked spin outs in Scotland between 1997 and 2008 found that of the 200 examined 30\% had failed and only $15 \%$ were still in business and employing more than 10 people. Indeed, the impact of spin out activities may have perhaps been overplayed (though it clearly makes good headlines for universities, thereby increasing esteem indicators). Harrison and Leitch (2010, p. 1243) argue that 'the belief in the efficacy of the university spin-off is based less on substantive rationality than on voodoo...'. One of the main barriers, the authors report, is the 'entrepreneurial academic' who 'may not necessarily be growth-oriented' (ibid, p. 1255). Rasmussen et al (2011, np) also report that 'specific competencies for venture creation had to be developed or acquired' by academics (including the rather untraditional academic 'competencies' of 'opportunity refinement, leveraging and championing'). In any case the Scottish University 
spin out study (Targeting Innovation, 2008) reports that 'No Scottish universities are believed to make money from spin-outs'.

Such entrepreneurial activity has had other impacts on the university, however. Thus, a poll of 103 'knowledge-transfer officers' commissioned by the Association for University Research and Industry Links (Auril), as reported in the Times Higher Education (THE) supplement (25.08.2011 [8]), found that "just over two thirds say that links with business are more important now than they were five years ago to those seeking to rise through the ranks'. Executive director of Auril, Philip Graham, commented that though this is positive much more needs to be done since $80 \%$ of those polled still thought that "promotion depends more on research reputation' (ibid).

Universities have traditionally offered immortality in exchange for cash, though as Miyoshi (2002, p. 57) points out in recent times 'the development office dealing with grants and endowments [has become] one of the most active parts of the university'. Thus, in 1990 the University of Aberdeen converted its ancient library in King's College into the Robert Maxwell Conference Centre (and Gift Shop). However, in the midst of revelations of pension fund plundering following his untimely demise, the plaque outside the centre bearing his name mysteriously disappeared. At the time this was widely put down to a 'student prank', though tellingly, it was never replaced and instead the venue was renamed the King's College Conference Centre. More recently, Oxford University sought to hide its embarrassment over its links with Rupert Murdoch (specifically the endowment of an eponymous Chair of 
Language and Communication) in the wake of the News of the World phone hacking scandal by saying it had turned 'bad money into good' (THE 14.07.2011 [9]).

Sponsorship deals with industry are common. For example, the involvement of the arms industry in higher education, 'sponsoring students through engineering programmes, corunning courses with university departments, offering student placements, giving equipment to departments and so on, in addition to wider research-based relationships and investments via pension plans' is well documented (Stavrianakis, 2009, p. 507). Recently, it was announced that Durham University had succeeded in raising money for the undeniably worthy cause of funding scholarships for women from Afghanistan. Unfortunately, it transpired that $£ 125,000$ of this had come from British American Tobacco and the university was urged 'by a senior official at Cancer Research UK' to return it (THE, 03.06.2011 [10]). Not to be outdone, my own institution has launched an 'Adopt a Book' scheme to raise money to buy library books: 'For every $£ 30$ you donate, we will recognise your support by placing a bookplate inside the front cover of a library book' (Stirling minds, 2011, p. 26). (Let us hope that this entrepreneurial move causes the university no embarrassment: 'This book adopted by President Bashar al-Assad...')

Wissema discusses transdisciplinary research in terms of science, technology and design which he allows since this is not a (girlie) 'art, like painting...or composing music' but is based on the manly ideals of 'solid engineering' (p.38). He is eerily silent on the humanities, a trend noted by Miyoshi (2002, p.56) who observes that both Kerr's (1963) influential Uses of the university, and Slaughter and Leslie's (1997) Academic capitalism 'have nothing 
whatever to say about the humanities, as if this branch of learning had already vanished' (Miyoshi, 2002, p.69). Indeed, Miyoshi argues, the humanities are in retreat 'no longer desired or warranted' in the new 'global university' (p.56), or they become transmuted, repackaged in consumable form as 'media, entertainment, and tourism' (ibid). (Either way, the possibility for the humanities to provide radical critique is curtailed - which only goes to show just how possible it is, in the current discourse, to not speak of the university). This discursive rebranding of the arts and humanities is evident in the UK with the Arts and Humanities Research Council (AHRC) disbursing £16m for the setting up of 'creative economy hubs' aimed at 'increasing knowledge exchange', 'building partnerships with industry' and 'boosting entrepreneurialism' (Research Fortnight, 16.08.2011 [11]). Understandably upbeat about this, Professor Evelyn Welch, Vice-Principal for Research and International Affairs at Queen Mary College, London University (one of the winners) is quoted as saying this is beneficial for the academics as 'they get the sense that the work they are doing makes a real difference’ (about $£ 4$ million worth [12]). In a bid to counter the unfortunate misconceptions concerning the importance attached to the arts and humanities by the present government (occasioned by the total withdrawal of state funding for teaching these subjects in English universities), David Willets professes to 'love' the humanities and says it is one of his 'three priorities' as minister (THE 04.08.2011 [13]), the other two being somewhat more plausible. But he would probably be less enamoured of those 'Unruly academics', such as Stefan Collini, who complain about 'the tyranny of outside funding' (quoted in THE 29.07.2011 [14]) which requires academics to 'incur expenses' for research (a key indicator of excellent academic performance) arguing that 'much good work in the humanities only needs a stimulating intellectual environment, good libraries and time' (ibid). 
The AHRC's 'creative-economy hubs' initiative is one example of the concentration of research funds acting as a nudge (Thaler \& Sunstein, 2008) towards more collaborative research. Concentration of funding is also evident in the cutting of small grants by both the ESRC and NERC [15], but if market manipulation and the concentration of research funds mainly in the self-appointed premier league of research intensive universities, the Russell Group - was the aim of the research assessment exercise carried out in the UK in 2008, then it didn't quite work out that way. At least it didn't until HEFCE (Higher Education Funding Council for England) shifted the goalposts altering the 'slope' of the formula for distribution of funds after the event :

In a letter to universities in England and Northern Ireland, the funding council says it will change the distribution of funding for $2^{*}, 3^{*}$ and $4 *$ work, as judged by the 2008 Research Assessment Exercise. The old weightings were 1:3:7. The new weightings will be 1:3:9.

First estimates ... show Oxford and Cambridge gaining about $£ 4 m$ a year between them, a rise of about 3 per cent, with the losers scattered among the English members of the various university groupings.

(Research Fortnight, 03.02.10 [16] )

It is to be profoundly hoped that the next round of research assessment, the Research Excellence Framework, doesn't give rise to similar recalcitrance. 
The creation of value through the exploitation of knowledge requires to be nurtured through a range of managerial procedures and while less state regulation may be an aspiration of the 3GU, at present it is very much part of the university apparatus in the UK as elsewhere, particularly in the form of research assessment. Research assessment may ostensibly be for the purpose of disbursement of public funds for research but its significance certainly goes wider for the university that aspires to World Class status. Research assessment forms a key part of the discursive milieu of performativity within which academics currently work and the management of this process has become a central concern for university managers. Thus, the THE (12.05.2011) IT in HE supplement (p. 16) reports that: 'To many university administrators, RIM [Research Information Management] is a tool that gets them through the ordeal of the government's funding trials every five to seven years'. However, the report goes on,

many British academics dislike the very idea of Research Information Management. It smacks too much of Big Brother; it feels like a conspiracy by the IT department and senior management to limit academic freedom by micromeasuring researchers' performance...

But it seems that precisely because 'it makes both academics and administrators more productive' many managers in higher education have discovered the joys of RIMming.

As noted by Reed and Deem (2002, p. 137) such practices enable individuals as well as departments to be more easily compared, ostensibly in the interests of greater 'transparency'. 
Typically and routinely, spreadsheets are produced of the activity profiles of staff, broken down to show individual academic's 'outputs' in key indicator journals. As one respondent quoted in the report, Developing tools to inform the management of research (Jisc, 2010, p.21; emphases added), says,

Our holy grail is a dashboard for every academic that benchmarks them against peer groups and our own internal targets. It should help managers to decide which themes to target and where to invest...

(Thus we are 'dividualised' [Deleuze 1995, p.180], endlessly dissected and opened up to scrutiny). Reed and Deem (2002, p. 138) go on to suggest that while the introduction of these 'new technologies of control' helps senior management to keep a 'firmer grip' on academics it may introduce new problems arising from resistance to these practices. However, in this they may be mistaken. Evidence suggests that academics are rather more ambivalent than might be expected. While they may dislike the notion of micromanagement many academics have embraced the notion of research assessment, demonstrating a considerable enthusiasm and evident desire to submit to the process (Watson, 2008). As Lacan famously said, 'le desire de l'homme est le desire de l'autre' - we desire what the other desires of us (Fink, 1995). In the Australian Excellence in Research for Australia (ERA) exercise, for example, academic journals were ranked from A* ('Virtually all papers they publish will be of a very high quality'; $5 \%$ of journals) to C (Journals 'that do not meet the criteria of higher tiers'; 50\%). This occasioned, according to Vanclay (2011, p. 265), 'some degree of game playing'. Confirming this, Richard Bosworth (2011) says that academics 'expended a huge effort' 'in 
ensuring that the place where they themselves published was ranked as high as possible' and goes on, there were many 'droll examples of rampant protectionism in this regard'. (The collective disappointment felt when this aspect of the assessment exercise was abandoned must have been palpable.) The need to publish, and particularly to publish in high ranking journals, has been blamed for a recent increase in retractions of scientific papers (Fang and Casadevall, 2011). While only a relatively small percentage of these retractions were found to be due to 'misconduct' (17\% in their sample), the authors say, 'Misconduct represents the dark side of the hypercompetitive environment of contemporary science with its emphasis on funding, numbers of publications and impact factor' (ibid, np). And they quote an obesity scientist jailed for misconduct as saying, 'I had placed myself...in an academic position in which the amount of grants that you held basically determined one's self worth...everything flowed from that'. The desire to secure public funding for research may have other unforeseen and unfortunate consequences. A recent report, The resilience to fraud of the UK higher education sector finds that 'higher education is the worst at protecting against fraud of all publicly funded sectors' (cited in THE, 04.08.2011 [17]). Jim Gee, one of the authors of the report said, 'universities were particularly at risk of data being manipulated to secure public funding'.

Operating in an international competitive market requires the 'competitive ability to attract the best academics, students and research grants' (Wissema, 2009). Possibly surprised and irritated at the decision of most English universities to charge the maximum $£ 9000$ fees for undergraduate students to be introduced in 2012/13 following the recommendations of the 
Browne Report (2010), David Willetts has announced that universities will face open competition for the most academically able students (defined as those gaining three 'A' level grades at A,A,B or better) while 20,000 places will be stripped out of core allocations and auctioned off to the lowest bidders (i.e. those institutions charging fees of $£ 7,500$ or less). This move has already generated a new entry in the university lexicon: David Allen (Deputy CEO [sic] at Exeter University) says that in future there will be 'two types of university: AAB universities and £7.5k universities’ (THE 28.07.2011 [18]). This will create, it has been argued, an 'English Ivy League' of elite universities which will need to compete in an international transfer market for the best academics (as well as students, see Multicultural organisation). Under the circumstances, Mr Allen is reported as saying, "why should we pay the same as Aberdeen? Why should we be tied to the affordability of the least able to pay when we are going to be one of the more successful universities'. It is uncertain why Mr Allen singled out Aberdeen University in this way, an institution which, though it is not Russell Group, has the laudable ambition 'to enter the top 100 universities in the world' (former Principal and Vice Chancellor, C Duncan Rice [19]). Mr Allen's remarks suggest however, that Aberdeen University has some way to go before the aim of being 'recognised, locally, nationally and internationally as a broad-based university that delivers innovative and excellent teaching and research' (University of Aberdeen, Brand Toolkit, p. 3 [20]) is fully realised.

The ability to operate in an international competitive market requires the adoption of new working practices among academics and the effective and efficient utilisation of resources. 
A recent report on 'workspace utilisation' [21] says that with budget cuts 'institutions are increasingly under pressure to reduce their estate costs by rethinking the way space is utilised' (Pinder et al, 2009, p.7). This has seen the nostalgically familiar 'cellular office' give way to other arrangements such as the open-plan office, the combi-office and most radically, the non-territorial office, 'in which people occupy workspaces as and when they need them' (p.4). This may increase levels of physical disorderliness in open work areas with unforeseen consequences. Recently published research on the links between perceived disorder and stereotyping suggest that, 'disorder increases the need for structure and, thus, the goal to create order...[S]tereotyping is an effective mental way to reach this goal; that is, to satisfy the desire for structure that is activated by physical disorder' (Stapel and Lindenberg, 2011: 253); a finding which has considerable implications with respect to the design of workspaces. At least it would if it hadn't been announced in the journal Science, which had published the piece, that Stapel had been involved in 'substantial' fraud and thus the journal has posted an 'Expression of concern' about this work. Stapel himself has blamed the pressure to publish (Metro, 3.11.2011, p.19).

Though, interestingly, the volume of territory that can be commanded remains a good indicator of personal power and prestige in the university. Changing demands on workspace design include the requirement to encourage inter and transdisciplinary research, meeting the needs of various 'unbounded', 'cross-boundary' and 'blended' professionals (Whitchurch, 2009); and the need to attract, retain and develop 'talented people in an increasingly competitive and globalised higher education market' (Pinder et al, 2009, p.5). The desire to reduce occupant density 'below the UK average of $11.8 \mathrm{~m}^{2}$ per person' (i.e. to increase 
occupant density) has perhaps contributed to the rise in working from home among UK academics. The report estimates in one instance that the move to open plan offices, intended to increase opportunities for contact and collaboration between academics, resulted in an $11 \%$ rise in working from home (p.18) with, one supposes, a concomitant reduction in these same opportunities. One consequence of this has been a subtle (or not so subtle) shift in the meaning attributed to 'academic freedom'.

Academic freedom is a cherished, if mythical, belief among academics: a focus for comforting nostalgic reflection in a time of turbulence perhaps. Yet it is something of an empty signifier. Commenting on the lack of consensus surrounding its meaning, Tight (1988, p. 2) says 'Given the nature of academics and academic life - an area of endeavour that does not rate agreement very highly - this should not be at all surprising'. In an interesting methodological approach Tierney (2004) traces the meanings attached to 'academic freedom' over the course of the 20 th century through the 'campus novel'. In the latter part of the 20th century, Tierney sees a movement away from the earlier concerns of academic freedom with conscience and truth towards questions of tenure and its loss (often occasioned by sexual transgression). In the 21 st century however, we may perhaps be witnessing another shift. Indeed, loss of academic freedom is a frequent complaint among academics (see, for example, Billot, 2010; Watson, 2010). In response to this Kolsaker (2008, p.516) says 'a casual visitor to an English university may be surprised, therefore, to encounter an environment where academics seemingly come and go as they please, have a relatively free hand in course design, and disappear to do "real work" (research) for days on end' and adds, 'faced with this reality, we need to consider whether authority is really sapping away from 
academics'. In the current discourse then, it seems that academic freedom has been reduced to flexible working. As a result of this the boundary between work and leisure becomes increasingly blurred. De Certeau (1993) talks about la perruque, the wig, as a metaphor for the private work an individual carries out under the guise of doing their employer's business, but increasingly, academics engage in a reverse process, covertly engaging in work while appearing to enjoy private time. (Thus the practice of concealing Deleuze and Guattari inside a 'chick lit' cover, as one colleague confesses to do in bed on a Saturday morning, in an effort to hide her proclivities from her husband.)

The 3GU aspires to independence from state regulation (No state interference). Terence Kealey, Vice Chancellor of the University of Buckingham, the UK's only 'independent' university, argues that 'only when [universities] are independent will they promote independence of thought' (Kealey, 2011, p. 13). There is a degree of ambiguity in this, however. Elsewhere in the article Kealey complains that scholars cannot be trusted: in a recent survey of research looking at the risks of certain heart drugs, he claims, it was found that research sponsored by 'neutral' bodies [sic] such as charities or government found the drugs to be more dangerous than studies funded by the drugs companies themselves. This raises the interesting question for the university of independence of what and from whom?[22]

Indeed, Wissema's model of funding does not envisage a complete retreat by the state but rather money is channelled through independent bodies. In this way the state is seen to adhere to the much appealed to 'Haldane Principle' which is supposed to ensure universities' 
autonomy in determining the direction of research free from political interference. This somewhat elastic principle has recently been stretched by research council moves aimed at 'shaping capability'[23] and has perhaps reached near breaking point with the AHRC's embrace of UK Prime Minister, David Cameron's pet 'Big Society' project, leading to the mass resignation of the AHRC peer review college. The Guardian (19.06.2011 [24]) reports however that 'The current AHRC chairman Sir Alan Wilson, said that he didn't understand why people were getting "quite worked up about it" and warned against taking "a small group of people too seriously and as being representative of our community"'[25].

Finally, cosmopolitanism. Wissema defines this in terms of a global market in which English is the 'daily language'. Indeed, cosmopolitanism provides a cover for the neo-colonial feeding frenzy engaged in by Western universities for international students (Watson, 2010). Thus 'cosmopolitanization is not...a symmetrical and autonomous process; it may well be the product of asymmetries, dependencies, power and force' (Beck and Grande, 2010, p. 418). Indeed, international students have become 'cash cows' (Forkert, 2011), the recruitment of whom universities 'can't afford to be too choosy' about, according to an email sent by Professor Helen Beebee, Head of the School of Philosophy, Theology and Religion at the University of Birmingham (THE 11.08.2011 [26]): thereby revealing the irony inherent in Nussbaum's (1997, p. 8) definition of cosmopolitanism as recognising that which is 'intrinsically valuable' about persons. Alternatively, international students are positioned as 'scape goats': ‘bogus' or 'terror suspects' (Forkert, 2011, p. 171). In this way cosmopolitanism undergoes a discursive shift re-emerging as xenophobia within the neoliberal Western university (ibid, p. 174). The temptations of internationalisation are great, 
though this is not without its dangers. Thus, the University of Wales has recently been censured by the Quality Assurance Agency about its worldwide college links. BBC Wales reports that 'the links included one with a Malaysian pop star with bogus degrees and a college in Bangkok said to be operating illegally’ [27].

So, there we have it. The functional university, operating 'in accordance with the tenets of perfect competition theory' (Collini, 2011, p.24) and becoming increasingly independent of the nation state (though this clearly does not apply to the London School of Economics state funding playing a significant role, albeit the state in question was Gaddafi's Libya [28]). With all this in mind, should we perhaps ask if there is room for a dysfunctional university, a university that in a sense opposes the call for functionality? Is there (still) a role for a university as a critical and radical institution? If so, what would it look like and what would it be doing?

\section{'How can we not speak of the university': Towards the dysfunctional university...}

The foregoing illustrates some of the 'risks to be avoided' (Derrida, 1983, p. 3) by the aspiring $3 \mathrm{GU}$ but is that all? What does this analysis tell us about the principle of reason underpinning the $3 \mathrm{GU}$ with its core function the exploitation of know-how and its objective the creation of value? As Derrida, (1983, p. 8; emphasis added) says, 'To respond to the call of the principle of reason is to "render reason", to explain effects through their causes, rationally; it is also to ground, to justify, to account for on the basis of principles or roots'. 
Within the discourse of excellence, value is given meaning as the return on investment. The functionality subscribed to by the university in this discourse is the functionality of the market, but as Stronach and Clarke (2011, np) point out "the "knowledge economy" is not some inevitable functional relation between education and the global economy: it is a fragile and somewhat demented extension of the economic model that itself crashed in $2007^{\prime}$. Thus, functionality and the principle of reason cannot be grounded in the rationality of the market. But, 'value' is a polysemic term which encompasses both the economic and, especially in its plural form, a moral dimension related to 'notions of social and cultural worth' (Kearnes and Wienroth, 2011, np; emphasis added). Can this concept - social and cultural worth - enable value to be reclaimed for the university? Arguing for 'the human capacity to differentiate legitimate and illegitimate means of rendering criticism and judgement' Boltanski and Thévenot (2006, cited in Annisette and Richardson, 2011, p. 231) have developed a 'sociology of worth' as worlds or orders giving rise to multiple bounded rationalities providing frames for justification. Boltanski and Thévenot identify six orders of worth, each of which is 'incompatible with, and therefore stands in critical relation to, all the others' (p.232). These orders of worth are: civic; industrial; domestic; market; inspired; and fame: 'Each defines the good, the just, and the fair - but according to different criteria of judgement' (Stark, 2008, p. 21). Negotiating these multiple rationalities requires compromise between different orders of worth but whereas, according to Stark (2008), Boltanski and Thévenot 'see orders of worth as making action possible by resolving problems of uncertainty' arising between different orders of worth (p. 22), Stark himself sees the mix of 'evaluative principles' which underlie different orders of worth as creating uncertainty 'and 
therefore as opening opportunities for action' (ibid). Moreover, he goes on 'it is precisely this uncertainty [rather than risk] that entrepreneurship exploits. Entrepreneurship is the ability to keep multiple evaluative principles in play and to exploit the resulting friction of their interplay' (ibid, p. 23: original emphasis). This gives rise to a 'productive dissonance' in an 'unruly search' for what is valuable (Stark, 2009, p.15).

The analysis presented in this paper points up the delinquencies to which the university is susceptible if functionality is understood narrowly within the order of worth of the market alone, while simultaneously (and paradoxically), Stark's analysis indicates that this approach is less likely to give rise to the kind of productive dissonance that would foster entrepreneurial activity anyway. Rather the concept of 'value' as the principle of reason underpinning the university needs to be kept in play between irreducible orders of worth (civic; industrial; domestic; market; inspired; and fame). Derrida (1983, p.13) argues that the examination of such evaluations is 'one of the tasks most indispensible to the exercise of academic responsibility, most urgent for the maintenance of its dignity'. But maybe dignity doesn't strike quite the right note. Kavanagh (2009, p.599) says that the university is, and has always been, a foolish institution,

...because it takes work to create order within play, play always (subliminally) reminds us that the world is fundamentally chaotic and that any meaning within this chaos is always provisional and artificial. The Fool's work of play then is to institutionalize order and at once to open up order to de-institutionalization. Through its role as playmaker, the Fool puts an 
institution 'into play', which means that work must be done to either recreate

or de-stabilize the institution. In this way, the Fool's ability and

license to play is paradoxically central to both institutionalization and

de-institutionalization.

Perhaps the function of the university as Fool needs to be recognised more explicitly. Perhaps what is needed is a department, or better still, a transdisciplinary institute (!) of dysfunctionality, lavishly funded from all quarters, and founded frankly on the logic of 'disoriented' research. Would this provide a role at last for the humanities in the 3GU?

\section{References}

Annisette, M., \& Richardson, A. J. (2011) Justification and accounting: Applying sociology of worth to accounting research. Accounting, Auditing \& Accountability Journal, 24(2), 229-249.

Bailey, L. (2009) Lacan: A beginner's guide. Oxford: Oneworld Publications.

Barnett, R. (1997) Realizing the university. London: Institute of Education.

Barnett, R. (2000) Realizing the university in an age of supercomplexity. Buckingham: Society for Research into Higher Education and Open University.

Beck, U., \& Grande, E. (2010) Varieties of second modernity: The cosmopolitan turn in social and political theory and research. The British Journal of Sociology, 61(3), 409443. 
Billot, J. (2010) The imagined and the real: Identifying the tensions for academic identity. Higher Education Research \& Development, 29(6), 709-721.

Bosworth, R. (2011) From where I sit. Bowl out the measurers. Times Higher Education 23.06.2011. Available at: http://www.timeshighereducation.co.uk/story.asp?storycode=416553 [Accessed: 24.07.2011].

Browne, J. (2010) Securing a sustainable future for higher education. (Browne report). London: Dept Business, Innovation and Skills.

Collini, S. (2010) Browne's Gamble. London Review of Books 32(1), 23-25. Available: http://www.lrb.co.uk/v32/n21/stefan-collini/brownes-gamble [Accessed: 05.10.2011].

De Certeau, M. (1988) The practice of everyday life. Berkeley and Los Angeles: University of California Press.

Delanty, G. (2001) The university in the knowledge society. Organization, 8(2), 149-153.

Deleuze, G. (1995) Negotiations. New York: Columbia University Press.

Derrida, J., Porter, C., \& Morris, E. P. (1983) The principle of reason: The university in the eyes of its pupils. Diacritics, 13(3), 3-20.

Dickson, D.R. (1998) The Tessera of Antilia. Utopian brotherhoods and secret societies in the early seventeenth century. Leiden: Die Deutsche Bibliotek.

Doherty, R. (2011) For the university. London: Bloomsbury. 26 
Europa Communiques de Presse Rapide. (2006)

Europe needs modernised universities, says European Commission. Available online at: $\underline{\text { Http://europa.eu/rapid/pressReleasesAction.do?reference=IP/ }}$ 06/592\&format=HTML\&aged=1\&language $=$ EN\&guiLanguage $=f r($ accessed 7 june 2010).

Fang, F. C., \& Casadevall, A. (2011) Retracted science and the retraction index. Infection and Immunity, doi:10.1128/IAI.05661-11

Fink, B. (1995) The Lacanian subject : between language and jouissance. Princeton, NJ: Princeton University Press.

Forkert, K. (2011) International students and the globalisation of higher education. In M. Bailey, \& D. Freedman (Eds.) The assault on the universities. A manifesto for resistance. (pp. 168-178). London: PlutoPress.

Gibbons, M., Limoges, C., \& Nowotny, H. (1994) The new production of knowledge: The dynamics of science and research in contemporary societies. London: Sage Publications Ltd.

Harrison, R. T., \& Leitch, C. (2010) Voodoo institution or entrepreneurial university? spinoff companies, the entrepreneurial system and regional development in the UK. Regional Studies, 44(9), 1241-1262.

Inayatullah, S. (1998a) Causal layered analysis Poststructuralism as method. Futures, 30,. 815-829. 
JISC. (2010) Developing tools to inform the management of research. http://www.jisc.ac.uk/whatwedo/projects/rimtools.aspx, [accessed: 24.08.2011].

Kavanagh, D. (2009). Institutional heterogeneity and change: The university as fool. Organization, 16(4), 575-595.

Kearnes, M., \& Wienroth, M.(2011) Tools of the trade: UK research intermediaries and the politics of impacts. Minerva, 49, 153-174.

Kealey, T. (2011) Lesson from the land of the fee. The Wednesday Essay, The Independent, 10.02.2011. Available online at: http://www.independent.co.uk/news/education/higher/the-university-debate-what-theivy-league-can-teach-britain-2215930.html [Accessed 31.08.2011]

Kerr, C. (1963) The uses of the multiversity. Cambridge: Harvard University Press.

Kolsaker, A. (2008) Academic professionalism in the managerialist era: A study of English universities. Studies in Higher Education, 33(5), 513-525.

Lefebvre, H. (1991) The production of space. Oxford: Blackwell

May, T. (2005) Transformations in academic production. European Journal of Social Theory, 8(2), 193-209.

Miyoshi, M. (2002) The university in the 'global' economy. In K. Robins, \& F. Webster (Eds.), The virtual university? knowledge, markets and management. (pp. 49-85). Oxford: Oxford University Press. 
Nussbaum, M. C. (1997) Kant and stoic cosmopolitanism. Journal of Political Philosophy, $5(1), 1-25$.

Olssen, M., \& Peters, M. (2005) Neoliberalism, higher education and the knowledge economy: From the free market to knowledge capitalism. Journal of Education Policy, 20(3), 313-345.

Pinder, J., Parkin, J., Austin, S., Duggan, F., Lansdale, M., Demian, T., \& Allenby, S. (2009) The case for new academic workspaces. Loughborough: Loughborough University.

Rasmussen, E., Mosey, S., \& Wright, M. (2011) The evolution of entrepreneurial competencies: A longitudinal study of university Spin - Off venture emergence. Journal of Management Studies, doi: 10.1111/j.1467-6486.2010.00995.x

Readings, B. (1996).The university in ruins. Cambridge, Mass.: Harvard University Press.

Reed, M., \& Deem, R. (2002) New managerialism: The manager-academic and technologies of management in universities - looking forward to virtuality. In K. Robins, \& F. Webster (Eds.) The virtual university? Knowledge, markets and management. (pp. 126147). Oxford: Oxford University Press.

Robins, K., \& Webster, F. (2002) The virtual university? In K. Robins, \& F. Webster (Eds.), The virtual university? Knowledge, markets and management. (pp. 3-19). Oxford; Oxford University Press. 
Slaughter, S., \& Leslie, L. L. (1997) Academic capitalism: Politics, policies, and the entrepreneurial university. Baltimore, MD: The Johns Hopkins University Press.

Stark, D. (2008) Searching questions: Inquiry, uncertainty, innovation. Working Papers Series, Center on Organizational Innovation, Columbia University, Available at: Www.Coi.Columbia.edu/pdf/stark_searching_questions.Pdf, [Accessed: 27.08.2011]

Stark, D. (2009) The sense of dissonance. Accounts of worth in economic life. Princeton: Princeton University Press.

Stavrianakis, A. (2009) In arms' way: Arms company and military involvement in education in the UK. ACME: An International e-Journal for Critical Geographies., 8(3), 505-520.

Stirling Minds (2011) Book your place in the library now. Stirling: University of Stirling).

Stronach, I., \& Clarke, J. (2011) Eight contentions for an educational future: Untimely rules for unruly times. Available at: http://scholar.google.co.uk/scholar?as_q=eight+knowledge+crash\&num=10\&btnG=Sear $\underline{\mathrm{ch}+\text { Scholar\&as_epq }=\& \text { as_oq }=\& \text { as_eq }=\& \text { as_occt }=\text { any } \& \text { as_sauthors }=\text { stronach }+\& \text { as_publ }}$ $\underline{\text { ication }=\& \text { as } \_y l o=\& \text { as } \_y h i=\& a s \_s d t=1 . \& a s \_s d t p=0 n \& a s \_s d t f=\& a s \_s d t s=5 \& h l=e n}$ [Accessed: 20.08.2011]

Targeting Innovation (2008) Scottish university spin-out study. Glasgow: Targeting innovation. Available online at: http://www.targetinginnovation.com/tlx/assets/documents/uploaded/general/Targeting\% 20Innovation\%20Spin-Out\%20Study\%202008.pdf [Accessed: 31.08.2011] 
Thaler, R. H., \& Sunstein, C. R. (2008) Nudge: Improving decisions about health, wealth, and happiness. Yale: Yale University Press.

Tierney, W. (2004) Academic freedom and tenure: Between fiction and reality. The Journal of Higher Education, 75(2), 161-177.

Tight, M. (1988) Editorial introduction. In M. Tight (Ed.), Academic freedom and responsibility. Milton Keynes: The Society for Research into Higher Education/Open University.

Times Higher Education (2011) IT in HE Supplement. London: Times Newspapers. (12.05.2011).

Vanclay, J. K. (2011) An evaluation of the Australian research council's journal ranking. Journal of Informetrics, 9(2), 265-274

Watson, C. (2010) Accountability, transparency, redundancy: Academic identities in an era of 'excellence'. British Educational Research Journal, DOI: $10.1080 / 01411926.2010 .508514$

Watson, C. (2011) Notes on the variety and uses of satire, sarcasm and irony in social research, with some observations on vices and follies in the academy. Power and Education,

Watson, C. (2008) Reflexive research and the (re)turn to the baroque. (or how I learned to stop worrying and love the university). Rotterdam: Sense. 
Whitchurch, C. (2009) The rise of the blended professional in higher education: A comparison between the United Kingdom, Australia and the United States. Higher Education, 58(3), 407-418.

Wissema, J. G. (2009) Towards the third generation university: Managing the university in transition. London: Edward Elgar Publishing.

\footnotetext{
${ }^{1}$ This was the question posed at a recent seminar sponsored by the Society for Educational Studies on 'The $21^{\text {st }}$ Century university. Functional or dysfunctional?' Held at the University of Stirling, 22.11.2011.

${ }^{2}$ In the sense that the aim of the Medieval university was to "pass on existing knowledge, professors were not expected to guide students toward independent research' (Dickson, 1998, p.6).

${ }^{3}$ Against those academics who dismiss this as a legitimate source of data for serious scholarship I argue that analysis of what might be referred to as the 'not quite academic press' (Inayatullah, 1998) is one way of operationalising the 'lived spaces' (Lefebvre, 1991) of academia.

\section{${ }^{4}$ http://www.dukece.com/ \\ ${ }^{5}$ http://en.wikipedia.org/wiki/Duke_Corporate_Education}

${ }^{6}$ Daily Telegraph (21.12.2009)

http://www.telegraph.co.uk/finance/yourbusiness/6860435/University-spin-off-activitycollapses.html

${ }^{7}$ http://business.scotsman.com/business/Capital-leads-UK-on-university.6755354.jp

${ }^{8}$ http://www.timeshighereducation.co.uk/story.asp?storyCode $=417223 \&$ sectioncode $=26$

${ }^{9}$ http://www.timeshighereducation.co.uk/story.asp?storycode $=416805$

${ }^{10}$ http://www.timeshighereducation.co.uk/story.asp?storycode $=416402$
} 
11

http://www.researchprofessional.com/\#/news/searches/0/?logQuery=28801021\&article=1098 $\underline{554}$

${ }^{12}$ http://www.qmul.ac.uk/media/news/items/hss/54259.html

${ }^{13}$ http://www.timeshighereducation.co.uk/story.asp?storyCode=417029\&sectioncode=26

${ }^{14}$ http://www.timeshighereducation.co.uk/story.asp?storycode $=416957$

${ }^{15}$ Economic and Social Research Council and Natural Environment Research Council respectively.

${ }^{16} \mathrm{http}: / /$ www.researchprofessional.com/\#/news/562112/2010/918416/?article=918241

${ }^{17}$ http://www.timeshighereducation.co.uk/story.asp?storycode $=417020$

${ }^{18}$ http://www.timeshighereducation.co.uk/story.asp?storycode=416945

${ }^{19}$ http://www.abdn.ac.uk/rae/

${ }^{20}$ http://www.abdn.ac.uk/documents/UOA-Brand-Toolkit.pdf

21

http://www.port.ac.uk/departments/faculties/cci/experience/newbuild/filetodownload,119929, en.PDF

${ }^{22}$ Buckingham has now been joined by BPP, the UK's first for-profit degree awarding institution. See also, The New College of the Humanities (aka 'Jamie's University'), A.C. Grayling's private university staffed by a stellar cast of 'academic luminaries'.

${ }^{23}$ This is EPSRC (Engineering and Physical Science Research Council) policy-speak: 'Shaping capability's goal is to align our portfolio to areas of UK strength and national importance' http://www.epsrc.ac.uk/Pages/default.aspx

${ }^{24}$ http://www.guardian.co.uk/education/2011/jun/19/academics-quit-over-big-society

${ }^{25}$ David Willetts has recently been lamenting the Haldane Principle and 'would like to find a way to exempt some science spending' from it. At a fringe meeting of the Conservative party conference (04.10.2011) he said, 'When the Chinese science ministry says, "Right, Mr Willetts, let's put money into a science project together" what am I supposed to do? I have no power to do it...All I can do is say "yes, that's a good idea" and then go back to the research councils'. (Research Fortnight Today, \#3772, 05.10.2011).

${ }^{26} \mathrm{http}: / / \mathrm{www} \cdot$ timeshighereducation.co.uk/story.asp?storycode $=417092$ 
${ }^{27}$ http://www.bbc.co.uk/news/uk-wales-13862552. The University of Wales has since announced that it is to end all external degree validation in the UK and abroad.

${ }^{28}$ Howard Davies, Director of the London School of Economics, was forced to resign in 2011 over links with former Libyan leader Colonel Muammar Gaddafi and the offer of a $£ 1.5 \mathrm{~m}$ donation for research (of which however, only £300,000 was actually paid [Daily Telegraph 05.03.2011]).

http://www.telegraph.co.uk/news/worldnews/africaandindianocean/libya/8360617/LibyaLSE-director-resigns-over-universitys-Gaddafi-links.html 